\title{
The influence of the polyene filipin on the extrinsic pathway of blood coagulation
}

Citation for published version (APA):

van der Plas, P. M., van Es, G., Kraan, L., \& Hemker, H. C. (1972). The influence of the polyene filipin on the extrinsic pathway of blood coagulation. Haemostasis, 1972-1973(1), 191-203.

https://doi.org/10.1159/000213985

Document status and date:

Published: 01/01/1972

DOI:

10.1159/000213985

Document Version:

Publisher's PDF, also known as Version of record

\section{Please check the document version of this publication:}

- A submitted manuscript is the version of the article upon submission and before peer-review. There can be important differences between the submitted version and the official published version of record.

People interested in the research are advised to contact the author for the final version of the publication, or visit the DOI to the publisher's website.

- The final author version and the galley proof are versions of the publication after peer review.

- The final published version features the final layout of the paper including the volume, issue and page numbers.

Link to publication

\footnotetext{
General rights rights.

- You may freely distribute the URL identifying the publication in the public portal. please follow below link for the End User Agreement:

www.umlib.nl/taverne-license

Take down policy

If you believe that this document breaches copyright please contact us at:

repository@maastrichtuniversity.nl

providing details and we will investigate your claim.
}

Copyright and moral rights for the publications made accessible in the public portal are retained by the authors and/or other copyright owners and it is a condition of accessing publications that users recognise and abide by the legal requirements associated with these

- Users may download and print one copy of any publication from the public portal for the purpose of private study or research.

- You may not further distribute the material or use it for any profit-making activity or commercial gain

If the publication is distributed under the terms of Article $25 \mathrm{fa}$ of the Dutch Copyright Act, indicated by the "Taverne" license above, 


\title{
The Influence of the Polyene Filipin on the Extrinsic Pathway of Blood Coagulation
}

\author{
P. M. van der Plas, G.van Es, L. KraAn and H. C. Hemker \\ Division of Hemostasis and Thrombosis, University Hospital Dijkzigt, Rotterdam, \\ Division of Hemostasis, Department of Internal Medicine, University Hospital, Utrecht \\ and Laboratory of Cardiovascular and Blood Coagulation Biochemistry, \\ Department of Internal Medicine, University Hospital, Leiden
}

\begin{abstract}
The inhibition by filipin in the extrinsic blood clotting system takes place at two sites: (1) at the interaction of factor VII, tissue thromboplastin and $\mathrm{Ca}^{++}$, and (2) at the prothrombinase level. Both formation and enzymatic activity of the prothrombinase are inhibited.

The cholesterol content of the lipid that is used to form the prothrombinase complex determines the

Key Words Polyene antibiotics Filipin Extrinsic coagulation pathway Stypven time Inhibition Cholesterol Lecithin degree of inhibition by filipin. The inhibition increases the higher the sterol content.

The adsorption of factors $\mathrm{X}_{\mathrm{a}}$ and $\mathrm{V}$ onto lipid surface is enhanced by filipin. This increased adsorption does not lead to an increase in prothrombinase production.
\end{abstract}

\section{Introduction}

Some polyene antibiotics, especially filipin, are inhibitors of blood coagulation [22-24]. This inhibition runs parallel with the action of polyenes on other systems, for instance the lysis of erythrocytes [23] and shortening of the life time of lipid bilayers $[23,28]$. It is conceivable that the same molecular mechanism underlies all these effects [23], in which case filipin would be a useful tool for the further investigation of the role of lipids in blood coagulation. This paper is concerned with the (exact) site(s) of inhibition by filipin in the extrinsic clotting system. An attempt was also made to find a

Received: October 16, 1972; accepted: January 30, 1973. 
relationship between the (chole)sterol content of the lipid needed for coagulation and the inhibition of this (these) site(s), because the action of filipin is considered to be dependent on the sterol content of the lipid involved [3].

\section{Materials and Methods}

1. Filipin was obtained from the Upjohn Company, Kalamazoo, Mich. and suspended in buffer as already described [23].

2. Human brain thromboplastin was prepared according to OWREN and AAS [21]; bovine brain thromboplastin was obtained analogously.

3. Veronal acetate buffer (to be further referred to as 'buffer'), $\mathrm{pH} 7.35$, was prepared according to MichaELIS [17].

4. Inosithin emulsions were prepared according to EsNOUF and JOBIN [5]. A solution of this lipid in ether was evaporated by a stream of $\mathrm{N}_{2}$ in the presence of buffer. Mixed inosithin/cholesterol emulsions were obtained in the same way, both lipid substances being dissolved in ether.

5. Lecithin/PS (cf. II, 13) and lecithin/PS/cholesterol emulsions were obtained similarly but with the lipids dissolved in chloroform.

6. Normal human citrated plasma was obtained as already described [23].

7. Factor $\mathrm{V}$ was determined by a one-stage method using a factor $\mathrm{V}$-deficient plasma obtained according to BORCHGREvinK et al. [1], in a setup after HEMKER et al. [9].

8. Factor $\mathrm{X}$ determination was a one-stage procedure using congenital deficient citrated plasma and human thromboplastin. Factor $\mathrm{X}_{\mathrm{a}}$ was determined as follows: $0.1 \mathrm{ml}$ Seitzfiltered plasma, $0.1 \mathrm{ml} \mathrm{RVV/lipid} \mathrm{mixture} \mathrm{(final} \mathrm{concentration} \mathrm{of} \mathrm{RVV:} 1,25 \times 10^{-3} \mathrm{mg} / \mathrm{ml}$ ) and $0.1 \mathrm{ml}$ sample were incubated for $30 \mathrm{sec}$ at $37^{\circ} \mathrm{C}$, then $0.1 \mathrm{ml} \mathrm{CaCl} 233 \mathrm{~mm}$ was added and the clotting time recorded.

9. A factor VII preparation from human citrated plasma was prepared according to SwART [26]. This preparation contained $100 \%$ factor VII, $1 \%$ factor X, $1 \%$ factor II and no detectable factor $\mathrm{V}$.

10. As a factor $X_{a}$ preparation human serum was used (decalcified if necessary). Blood was collected in glass tubes without anticoagulant and allowed to stand for $3 \mathrm{~h}$ at $37^{\circ} \mathrm{C}$. The supernatant serum was stored in frozen condition and thawed only once.

11. As a preparation of factor $\mathrm{V}, \mathrm{Al}(\mathrm{OH})_{3}$-adsorbed human (citrated) plasma was used. In some cases human congenitally factor X-deficient plasma was used. Repeated adsorption with $\mathrm{A} 1(\mathrm{OH})_{3}$ took place according to SWART [26].

12. Russell's viper venom (RVV; Burroughs Wellcome), hirudin (Sigma) cholesterol $(\mathrm{BDH})$, lecithin from eggs (Merck), and inosithin (Associated Concentrates) were commercial preparations.

13. Phosphatidyl-serine (PS) dissolved in chloroform was kindly supplied by Prof. vAN DEENEN, University of Utrecht, The Netherlands.

14. Factor II-deficient plasma was prepared as described by KoLLER et al. [15].

15. Factor VII-deficient plasma was human congenitally deficient plasma or human artificially deficient plasma prepared according to LECHNER and DEUTSCH [16]. 
16. The stypven time was determined as follows: $0.1 \mathrm{ml}$ platelet poor citrated plasma; $0.1 \mathrm{ml} \mathrm{RVV} /$ lipid mixture (final concentration RVV, $1.25 \times 10^{-3} \mathrm{mg} / \mathrm{ml}$ ); $0.1 \mathrm{ml}$ filipin suspension $\left(14 \times 10^{-4} \mathrm{M}\right)$ or blank were incubated for $1 \mathrm{~min}$ at $37^{\circ} \mathrm{C}$, after which $0.1 \mathrm{ml}$ of $\mathrm{CaCl}_{2}$ 1/30 $\mathrm{M}$ was added and the clotting time recorded.

17. A two-stage clotting test to follow the influence of filipin on the formation of prothrombinase activity was performed as follows. A mixture of: $1 \mathrm{ml} \mathrm{RVV/inosithin}$ (final concentration RVV, $1.25 \times 10^{-3} \mathrm{mg} / \mathrm{ml}$ ); $1 \mathrm{ml}$ factor II-deficient plasma (diluted 1:5); $1 \mathrm{ml} 14 \times 10^{-4} \mathrm{M}$ filipin suspension or blank; $1 \mathrm{ml} \mathrm{CaCl}_{2} 1 / 20 \mathrm{M}$, was incubated at $37^{\circ} \mathrm{C}$, and at various intervals a $0.2-\mathrm{ml}$ aliquot was brought into $0.1 \mathrm{ml}$ of a mixture of 4 parts factors V-or X-deficient plasma; 1 part blank or filipin suspension $\left(35 \times 10^{-4} \mathrm{M}\right)$ and the clotting time recorded. Because filipin was added either to the incubation medium or to the test mixture, the final concentration in the latter was the same throughout.

18. The influence of filipin on the activation of factor VII by thromboplastin and $\mathrm{Ca}^{++}$ was studied as follows. A mixture of: $1 \mathrm{ml}$ factor VII preparation (various dilutions); $1 \mathrm{ml}$ human or bovine brain thromboplastin (various dilutions); $1 \mathrm{ml}$ filipin $\left(14 \times 10^{-4} \mathrm{M}\right)$ or blank, and $3 \mathrm{ml} \mathrm{CaCl}_{2} 1 / 40 \mathrm{M}$, was incubated at $37^{\circ} \mathrm{C}$ and at various intervals an aliquot of $0.2 \mathrm{ml}$ was brought into $0.1 \mathrm{ml}$ of a mixture of 5 parts factor VII-deficient plasma; 1 part lipid or thromboplastin; 3 parts blank or filipin suspension $\left(14 \times 10^{-4} \mathrm{M}\right)$, and the clotting time was recorded.

19. The adsorption of clotting factors onto lipids was in the presence of filipin performed after HEMKER and KAHN [8], with some slight modifications as follows: $0.9 \mathrm{ml}$ factor $\mathrm{V}$ or $\mathrm{X}_{\mathrm{a}}$ preparation, $0.2 \mathrm{ml}$ filipin-suspension (various concentrations) or blank, $0.2 \mathrm{ml}$ inosithin $3 \mathrm{mg} / \mathrm{ml}$ containing $20 \%$ cholesterol (w/w), $0.1 \mathrm{ml}$ of hirudin $(18 \mu \mathrm{g} / \mathrm{ml})$, $0.4 \mathrm{ml}$ of $\mathrm{CaCl}_{2}$ (several concentrations) or blank were combined and incubated for $10 \mathrm{~min}$ at $37^{\circ} \mathrm{C}$ after which one portion was centrifuged during 30 or 60 min at $115,000 \mathrm{~g}$ and $4{ }^{\circ} \mathrm{C}$, while another part was kept at $4{ }^{\circ} \mathrm{C}$. The supernatant fluid was collected and the lipid concentration restored to the original level [11]. The factor $\mathrm{V}$ and $\mathrm{X}_{\mathrm{a}}$ determinations were carried out in 3 dilutions in duplicate for each supernatant fluid.

20. The haemolytic action of a filipin suspension was measured as described by KINSKY et al. [13] on human erythrocytes. The adsorbance was measured at $541 \mathrm{~nm}$. The lysis time was at least $30 \mathrm{~min}$.

\section{Results}

\section{A. Influence of Filipin on the Stypven Time Determination performed with} Lipids containing Various Amounts of Cholesterol

In earlier work we demonstrated that filipin does not inhibit the conversion of fibrinogen into fibrin by thrombin in normal human citrated plasma [23]. This is consistent with the fact that this reaction does not involve lipids.

The Quick thromboplastin time was, however, clearly inhibited by filipin. In the extrinsic clotting system inhibition might occur at the level of prothrombinase, because lipids have to be available for the formation of this 
Table I. Inhibition by filipin of the stypven time for lecithin/phosphadityl-serine containing various amounts of cholesterol ( $\%$ of lecithin $w / w)$

Coagulation times (sec) for different cholesterol contents

\begin{tabular}{|c|c|c|c|c|c|c|c|c|}
\hline \multirow[b]{2}{*}{$\begin{array}{l}\text { Lecithin } \\
\text { concentrations }\end{array}$} & \multicolumn{2}{|l|}{$0 \%$} & \multicolumn{2}{|l|}{$5 \%$} & \multicolumn{2}{|c|}{$10 \%$} & \multicolumn{2}{|c|}{$20 \%$} \\
\hline & & - & + & - & + & - & + & - \\
\hline $1,000 \mu \mathrm{g} / \mathrm{ml}$ & 10 & 10 & 10 & 10 & 11 & 10 & 12 & 11 \\
\hline $100 \mu \mathrm{g} / \mathrm{ml}$ & 12 & 12 & 14 & 13 & 16 & 14 & 17 & 13 \\
\hline $50 \mu \mathrm{g} / \mathrm{ml}$ & 15 & 14 & 16 & 15 & 18 & 15 & 20 & 15 \\
\hline $25 \mu \mathrm{g} / \mathrm{ml}$ & 20 & 18 & 21 & 18 & 23 & 19 & 25 & 18 \\
\hline $10 \mu \mathrm{g} / \mathrm{ml}$ & 32 & 24 & 32 & 24 & 34 & 24 & 37 & 25 \\
\hline $5 \mu \mathrm{g} / \mathrm{ml}$ & 42 & 28 & 44 & 29 & 46 & 30 & 47 & 30 \\
\hline
\end{tabular}

In all four columns the clotting times obtained in the presence of filipin (final concentration $3.5 \times 10^{-4} \mathrm{M}$ ) are given under the plus sign, the blank values under the minus sign. $0.15 \mathrm{mg}$ phosphatidyl-serine per mg lecithin was used throughout.

Table II. Inhibition by filipin of the stypven time for inosithin with various additions of cholesterol ( $\%$ of inosithin $w / w)$

\begin{tabular}{|c|c|c|c|c|c|c|c|c|}
\hline & \multicolumn{8}{|c|}{ Coagulation times $(\mathrm{sec})$ for different cholesterol additions } \\
\hline & $0 \%$ & & $5 \%$ & & $10 \%$ & & $20 \%$ & \\
\hline $\begin{array}{l}\text { Inosithin } \\
\text { concentrations }\end{array}$ & + & - & + & - & + & - & + & \\
\hline $1,000 \mu \mathrm{g} / \mathrm{ml}$ & 15 & 13 & 17 & 13 & 18 & 13 & 23 & \\
\hline $50 \mu \mathrm{g} / \mathrm{ml}$ & 21 & 16 & 23 & 17 & 25 & 16 & 30 & \\
\hline $33 \mu \mathrm{g} / \mathrm{ml}$ & 25 & 19 & 26 & 18 & 29 & 18 & 35 & \\
\hline $25 \mu \mathrm{g} / \mathrm{ml}$ & 30 & 23 & 33 & 23 & 35 & 22 & 40 & \\
\hline $10 \mu \mathrm{g} / \mathrm{ml}$ & 47 & 37 & 49 & 37 & 48 & 34 & 50 & \\
\hline
\end{tabular}

In all four columns the clotting times obtained in the presence of filipin (final concentration $3.5 \times 10^{-4} \mathrm{M}$ ) are given under the plus sign, the blank values under the minus sign. 


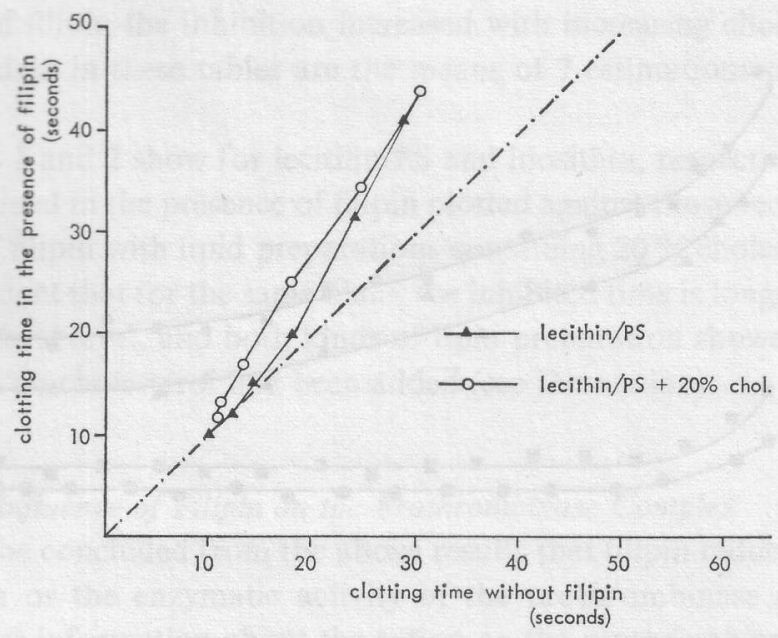

Fig. 1. Influence of filipin on stypven times obtained with various dilutions of lecithin/ PS with or without cholesterol. Final concentration of filipin $3.5 \times 10^{-4} \mathrm{M}$. Each point represents the mean of 7 estimations done in duplicate. The line through the origin represents the theoretical case that no inhibition takes place.

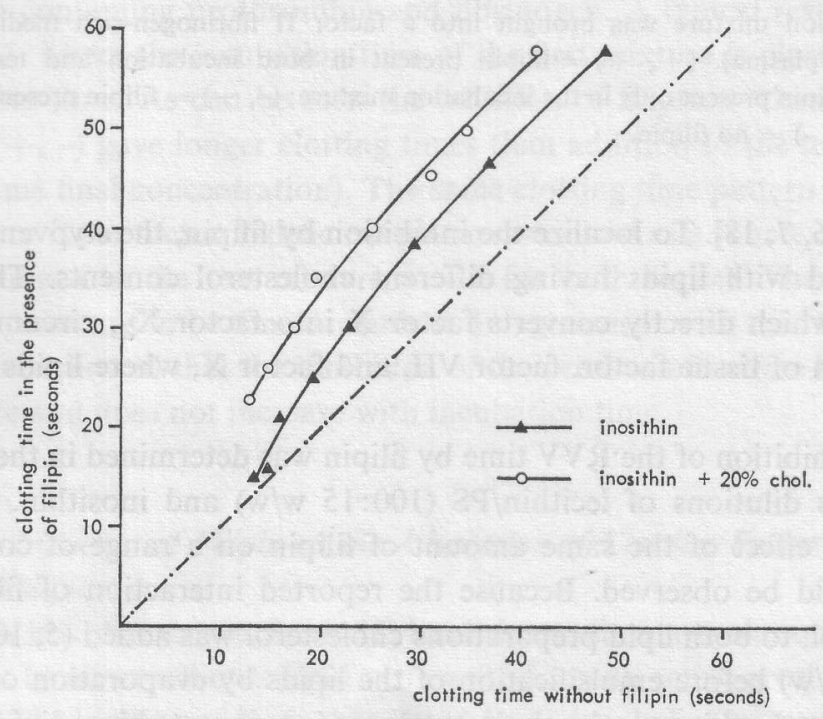

Fig.2. Influence of filipin on stypven time for various dilutions of inosithin with or without cholesterol. Final concentration of filipin $3.5 \times 10^{-4} \mathrm{M}$. Each point represents the mean of 7 estimations done in duplicate. The line through the origin concerns the theoretical case that no inhibition takes place. 




Fig. 3. Results of a two-stage clotting test showing the influence of filipin (final concentration $3.5 \times 10^{-4} \mathrm{M}$ ) on the development of prothrombinase. The prothrombinase in the incubation mixture was brought into a factor II fibrinogen-rich medium (factor X-deficient plasma). $(+,+)=$ filipin present in both incubation and test mixture; $(+,-)=$ filipin present only in the incubation mixture; $(-,+)=$ filipin present in the test mixture; $(-,-)=$ no filipin.

complex $[6,7,18]$. To localize the inhibition by filipin, the stypven time was determined with lipids having different cholesterol contents. The use of stypven, which directly converts factor $\mathrm{X}$ into factor $\mathrm{X}_{\mathrm{a}}$, circumvents the interaction of tissue factor, factor VII, and factor $\mathrm{X}$, where lipids also play a role.

The inhibition of the RVV time by filipin was determined in the presence of various dilutions of lecithin/PS $(100: 15 \mathrm{w} / \mathrm{w})$ and inosithin. Thus the inhibitory effect of the same amount of filipin on a range of coagulation times could be observed. Because the reported interaction of filipin with cholesterol, to both lipid preparations cholesterol was added $(5,10$, or $20 \%$ lecithin $w / w)$ before emulsification of the lipids by evaporation of ether or chloroform. In this way the cholesterol was incorporated into lipid micelles. The clotting times obtained in the presence or absence of filipin are given in table I (lecithin/PS) and table II (inosithin). These results show that the added cholesterol affected the clotting times only slightly or not at all. In the 
presence of filipin the inhibition increased with increasing cholesterol content. The data in these tables are the means of 7 estimations performed in duplicate.

Figures 1 and 2 show for lecithin/PS and inosithin, respectively, clotting times obtained in the presence of filipin plotted against those recorded in the absence of filipin with lipid preparations containing $20 \%$ cholesterol (w/w).

It is evident that for the same blank the inhibited time is longer the higher the cholesterol level, and both kinds of lipid preparation showed inhibition even when no cholesterol had been added (see Discussion).

\section{B. The Influence of Filipin on the Prothrombinase Complex}

It may be concluded from the above results that filipin reduces either the production or the enzymatic activity of the prothrombinase or both. To obtain more information about the action on the prothrombinase complex, a two-stage clotting test (see under Methods, No.17) was performed. The formation of prothrombinase was induced in an incubation mixture containing factor $\mathrm{V}$ and $\mathrm{X}$ (factor II-deficient plasma), RVV, lipid and $\mathrm{Ca}^{++}$. The conversion of prothrombin by this complex was assessed by subsampling in a mixture containing prothrombin and fibrinogen. A typical result is given in figure 3, where the incubation time of the first mixture is plotted against the clotting time. As can be seen the addition of filipin to the incubation mixture $(+,-)$ gave longer clotting times than addition to the test mixture $(-,+$; same final concentration). The same clotting time pattern was found when factor X- or factor V-deficient plasma was used as a source of factor II and fibrinogen in the test mixture ( $\mathrm{n}=7$ for both series). The inhibitory action appears not to be time dependent. In agreement with this, the control experiments showed that the inhibition of the prothrombin time by filipin is immediate and does not increase with incubation time.

\section{The Influence of Filipin on the Adsorption of Clotting Factor $X_{a}$ and $V$} by Phospholipids

Several investigators $[6,8,11,18]$ have shown that coagulation factor $\mathrm{X}_{\mathrm{a}}$ and $\mathrm{V}$ can be adsorbed onto lipid surfaces to form an active prothrombinase complex. The binding of $\mathrm{X}_{\mathrm{a}}$ is thought to be hydrophylic (by means of $\mathrm{Ca}^{++}$ bridges), that of factor $\mathrm{V}$ hydrophobic. This conclusion was drawn because low concentrations of $\mathrm{Ca}^{++}$ions enhance the adsorption of factor $\mathrm{V}$, whereas factor $\mathrm{X}_{\mathrm{a}}$ is adsorbed better at higher $\mathrm{Ca}^{++}$concentrations [8]. The influence 
of filipin on the adsorption of factors $\mathrm{X}_{\mathrm{a}}$ and $\mathrm{V}$ was studied by a modification of the experiments described by HEMKER and KAHN [8] and KAHN [11] (see under Methods, No.19). Tables III and IV, showing the calculated

Table III. Activity of factor $\mathrm{X}_{\mathrm{a}}{ }^{1}$

\begin{tabular}{|c|c|c|c|c|c|c|}
\hline \multirow[t]{2}{*}{$\mathrm{Ca}^{++}, \mathrm{mm}$} & \multicolumn{6}{|c|}{ [Filipin] in centrifugation mixture $\left(\times 10^{-5} \mathrm{M}\right)$} \\
\hline & 0 & & 16 & & 32 & \\
\hline & C & A & C & A & $\mathrm{C}$ & A \\
\hline 4 & 96 & 4 & 91 & 9 & 83 & 17 \\
\hline 46 & 79 & 21 & 76 & 24 & 66 & 34 \\
\hline 88 & 81 & 19 & 72 & 28 & 63 & 37 \\
\hline
\end{tabular}

1 Recovered from the supernatant fluid after centrifugation of a mixture of lipid, factor $\mathrm{X}_{\mathrm{a}}, \mathrm{Ca}^{++}$( 3 concentrations), and filipin (various concentrations) for $30 \mathrm{~min}$ at $110,000 \mathrm{~g}$, expressed as a percentage of the activity of the uncentrifuged filipinfree sample (under C). The calculated amount of adsorbed factor $\mathrm{X}_{\mathrm{a}}$ is shown under $\mathrm{A}$. Values represent the means of 3 to 5 experiments. All estimations were carried out in quadruplicate.

Table IV. Activity of factor $\mathrm{V}^{1}$

$\mathrm{Ca}^{++}, \mathrm{mm} \quad$ [Filipin] in centrifugation mixture $\left(\times 10^{-5} \mathrm{M}\right)$

\begin{tabular}{rrrrrrrr}
\hline & 0 & & 16 & & 32 & \\
\hline & C & A & C & A & C & A \\
\hline 0 & 76 & 24 & 32 & 68 & 24 & 76 \\
42 & 95 & 5 & 89 & 11 & 89 & 11 \\
84 & 95 & 5 & 89 & 11 & 83 & 17
\end{tabular}

${ }_{1}$ Recovered from the supernatant fluid after centrifugation of a mixture of lipidfactor $\mathrm{V}, \mathrm{Ca}^{++}$( 3 concentrations), and filipin (various concentrations) under conditions as indicated in table III. 
percentage of adsorbed clotting factor activity (column A), indicate no decrease of adsorption, and in the case of factor $\mathrm{V}$ even an increase. Control experiments concerning factor $\mathrm{V}$ and factor $\mathrm{X}$ activity in the supernatant fluids showed that the prolongation of clotting times, indicative of enhanced adsorption in samples containing filipin, cannot be due to this polyene in the supernatant fluids. In these coagulation tests the maximal final concentration of filipin was $10^{-5} \mathrm{M}$, which could nor prolong the clotting times for more than $1 \mathrm{sec}$, whereas the observed retardation indicative of enhanced adsorption was between 5 and $10 \mathrm{sec}$. Furthermore, no haemolysing activity was demonstrable in the supernatant fluid either before or after centrifugation. Since haemolysis occurs at a much lower concentration of filipin than is needed for the inhibition of coagulation, no inhibitory effect on clotting could be expected in the factor $\mathrm{V}$ and factor $\mathrm{X}$ determinations in the supernatant fluids.
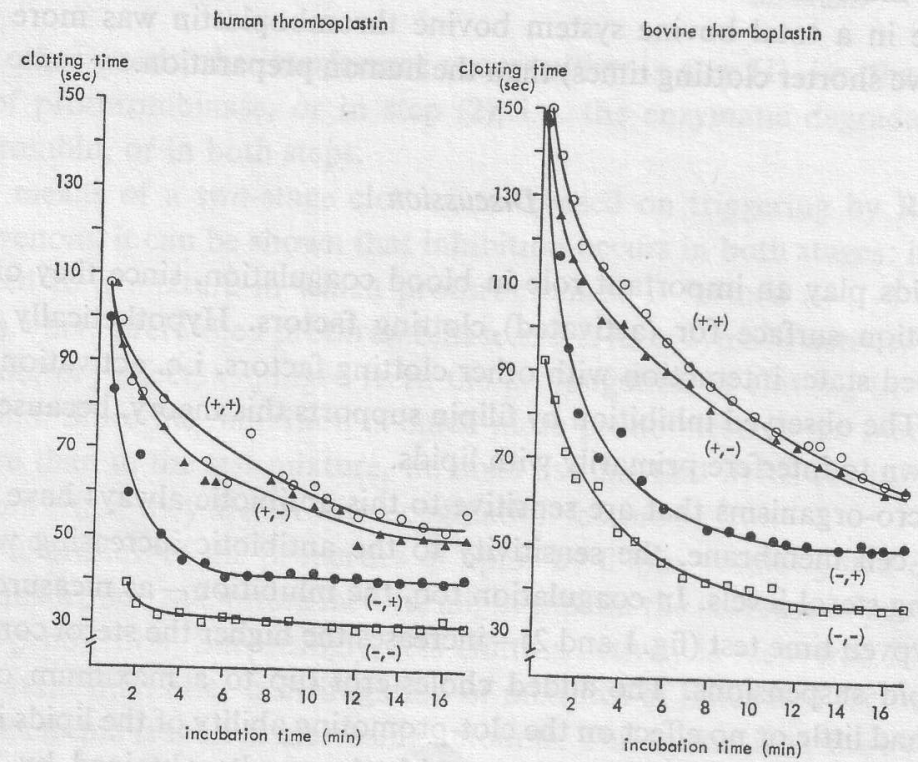

Fig.4. Activation of human factor VII by $\mathrm{Ca}^{++}$and human or bovine brain thromboplastin in the presence or absence of filipin. $(+,+)=$ filipin present in both incubation and test mixtures; $(+,-)=$ filipin present only in the incubation mixture; $(-,+)=$ filipin present in the test mixture; $(-,-)=$ no filipin. 


\section{D.The Influence of Filipin on the Activation of Human Factor VII by Human or Bovine Brain Thromboplastin}

A second level in the extrinsic clotting system at which lipids play a role is at the activation of factor VII by tissue thromboplastin and $\mathrm{Ca}^{++}$. According to several investigators $[4,7,10,19,27]$, thromboplastin can be split up into a lipid part and a protein part. To find out whether the lipid part of thromboplastin is important at this level, the activation of a purified factor VII preparation by bovine or human brain thromboplastin was studied by means of a two-stage clotting test (see Methods, No.18) with the same (final) amount of filipin in either the incubation $(+,-)$ or the test mixture $(-,+)$. The activation patterns obtained were all similar to that given in figure 3 for the two-stage stypven time determinations $(\mathrm{n}=3$ for the bovine and human thromboplastin tests), i.e. inhibition by filipin at the factor VII thromboplastin level was consistently observed. A representative result of the assessment of factor VII activation in the presence and absence of filipin is shown in figure 4 for both human and bovine thromboplastin. The difference in the shortest clotting times between bovine and human thromboplastin in this system must have been caused by species specificity of thromboplastin, because in a total bovine system bovine thromboplastin was more active (i.e. gave shorter clotting times) than the human preparation.

\section{Discussion}

Lipids play an important role in blood coagulation, since they offer an adsorption surface for (activated) clotting factors. Hypothetically in the adsorbed state, interaction with other clotting factors, i.e. activation, takes place. The observed inhibition by filipin supports this theory, because filipin is known to interfere primarily with lipids.

Micro-organisms that are sensitive to this antibiotic always have sterols in the cell membrane, the sensitivity to the antibiotic increasing with increasing sterol levels. In coagulation too, the inhibition - as measured with the stypven time test (fig. 1 and 2) - increases the higher the sterol content of the lipid suspensions. The added cholesterol (up to a maximum of $20 \%$ $\mathrm{w} / \mathrm{w}$ ) had little or no effect on the clot-promoting ability of the lipids in these experiments. This is in accordance with the results obtained by SøRBYE et al. [25] for clotting mixtures triggered by Russell's viper venom and $\mathrm{Ca}^{++}$ and indicates that cholesterol does not alter the mosaic structure of the lipid surface (alternating hydrophobic and hydrophilic sites) in any way affecting 
prothrombinase formation. This mosaic structure provides for the adsorption of both factor $\mathrm{X}_{\mathrm{a}}$ (hydrophilic) and factor V (hydrophobic). The degree of inhibition by filipin is not only dependent on the cholesterol content but also varies with the composition of the other added lipid and the lipids already present in plasma, for example with the ratio neutral to charged lipids. The inhibition pattern for a mixture of lecithin/PS $(100: 15 \mathrm{w} / \mathrm{w})$ therefore differs from that of inosithin. The action of both lipids can be inhibited when no additional cholesterol has been incorporated. There can be more than one reason for this. Firstly, the lipids may contain sterol themselves, as in the case of inosithin, and secondly, when a rather dilute lipid preparation is used (giving longer clotting times), the plasma lipid, which contains sterol, becomes a relatively large fraction of the total lipid present. On the basis of the results of these experiments and the fact that the interaction between fibrinogen and thrombin to form fibrin is not affected by filipin, we can only conclude that the inhibition must take place at the prothrombinase level:
$\mathrm{RVV}+\mathrm{X}$
$\mathrm{V}+\mathrm{Ca}^{++}$
lipid
(1)
$\frac{\mathrm{X}_{\mathrm{a}}+\mathrm{V}}{\text { lipid }+\mathrm{Ca}^{++}}$
(2)
$(-1)$

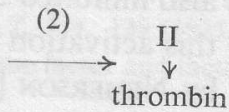

In other words, the interference occurs either in step (1), i.e. the formation of prothrombinase, or in step (2), i.e. the enzymatic degradation of prothrombin, or in both steps.

By means of a two-stage clotting test based on triggering by Russell's viper venom, it can be shown that inhibition occurs in both stages: if filipin is added to a mixture in which prothrombinase is formed $(+,-)$ or to a system where preformed prothrombinase exerts its enzymatic activity $(-,+)$, an inhibitory effect, as judged from the prolongation of clotting times, will be found. Since the inhibition is much more pronounced in the incubation mixture than in the test mixture, we must assume that lipids are influenced by filipin either they are set with coagulation factors or free.

An alteration of the properties of lipids by filipin, resulting in a decrase of the adsorption of clotting factors, might explain the decrease of prothrombinase production. Surprisingly, less clotting activity is recovered from the supernatant fluid after centrifugation of mixtures of lipids and factors $\mathrm{V}$ or $\mathrm{X}_{\mathrm{a}}$ when filipin is used in increasing amounts. This means that more clotting factors are adsorbed, possibly due to reorganisation of the structures attacked by filipin, resulting in a packing that is more suitable for adsorption. This is in accordance with the findings of KINSKY et al. [14], whu suggest that filipin interferes with the ability of cholesterol to stabilize the bilayer configuration 
of phospholipids. On the other hand, the increased adsorption (mainly of factor $\mathrm{V}$ ) does not mean that more active prothrombinase is formed, because filipin always inhibits and never promotes clotting. A possible explanation for these apparently contradictory results is that in the presence of filipin, factor $\mathrm{V}$ and factor $\mathrm{X}_{\mathrm{a}}$ are adsorbed at sites, at which they cannot cooperate to convert prothrombin into thrombin. The fact that the adsorption of factor $\mathrm{V}$ is influenced more strongly than that of factor $\mathrm{X}_{\mathrm{a}}$ probably means that filipin frees more hydrophobic sites in the lipid. The disturbance of lipid structures by filipin then would result in an increase in lipid surface for the adsorption of factor $\mathrm{V}$.

The amount of factor $X_{a}$ in the supernatant fluid decreases with increasing $\mathrm{Ca}^{++}$concentration. Factor $\mathrm{V}$ gives the reverse effect: higher $\mathrm{Ca}^{++}$ concentrations gives a higher recovery from the supernatant fluid. This is in agreement with the results of other investigators $[8,11]$.

The activation of a purified factor VII preparation by thromboplastin and $\mathrm{Ca}^{++}$is also inhibited by filipin. This supports the hyothesis that lipid is involved in this activation of factor VII, and is also in accordance with the work done by Nemerson [18], Nemerson and Pituick [19], Nemerson and SPAET [20] and WiLLIAMs [27], indicating that these factors together interact with factor $\mathrm{X}$ to produce factor $\mathrm{X}_{\mathrm{a}}$. This means that the lipid part of thromboplastin does indeed have two functions: one at the activation of factor VII and the other as an adsorption surface for the formation of prothrombinase complex.

\section{References}

1 Borchgrevink, C.F.; Pool, J.G., and Stormorken, H.: A new assay for factor V (proaccelerin-accelerin) using Russell's viper venom. J. Lab. clin. Med.55: 625 (1960).

2 Demel, R.A.: Monomolecular layers of lipids; Thesis, Utrecht, 1966 (Hoeyenbos N.V., Utrecht, The Netherlands).

3 Demel, R.A.; Crombag, F.L.J.; Van Deenen, L.L.M., and Kinsky, S.C.: Interaction of polyene antibiotics with single and mixed monomolecular layers. Biochim. biophys. Acta 150: 1 (1968).

4 Deutsch, E.; Irsigler, K. und Lomoschitz, H.: Studien über Gewebsthromboplastin. I. Reinigung, chemische Charakterisierung und Trennung in einen Eiweiss- und Lipoidanteil. Thromb. Diath. haemorrh. 12: 12 (1964).

5 EsNouf, F. and JoBIN, M.P.: Studies on the formation of the prothrombin converting complex. Biochem.J.102: 666 (1967).

6 Hanahan, D.J.; Barton, P.G., and Cox, A.: in Human blood coagulation, p. 24 (Leiden University Press, Leiden 1969).

7 Hecht, E. and WisngaARds, G.: On the functional resynthesis of thromboplastin from its fractions and various subsitutes. Thromb. Diath. haemorrh. 18: 223 (1967). 
8 HeMKer, H.C. and KAHN, M.J.P.: Reaction sequence of blood coagulation. Nature,

and and factor $\mathrm{X}$. A computer programme for obtaining reference tables for one-stage

10 Hvatum, M. and Prydz, H. System. Thromb. Diath. haemorrh. 27: 205 (1972). separable parts. Thromb. Diath. haes on tissue thromboplastin. Its splitting into two

11 KAHN, M.J.P. Studies. Diath. haemorrh. 21: 217 (1969).

12 KAHN, M.J.P.: Etude de l'action d'unulation factor V; thesis, Leiden (1970). nisme de la conversion de la proth un phosphoinositide anticoagulation sur le mecha-

13 KINSKY, S. C.; DEMEL, R. A., and lytic action of filipin and derivativ DEENEN, L.L.M.: Further studies onthe haemo-

14 Kinsky, S.C.; Luse, S. A.; Zopf, Diochim. biophys. Acta 135: 835 (1967), Interaction of filipin and derivatives D.; VAN DEENEN, L.L.M., and HAXBY, J.A.: electron microscopic observations with erythrocyte membranes and lipid dispersions:

15 Koller, F.; Loeliger, E. A., and Biochim. biophys. Acta 185: 844 (1967).

Acta haemat., Basel 6:1 (1951).

16 I

lichem Faktor VII-Mangel P.: Eine einfache Methode zur Herstellung von mensch-

17 Mrciath. haemorrh. 18: 252 (1967).

18 Nemerson, Y. The reaction Veronal-Puffer. Biochem. Z. 234: 139 (1931).

Biochemistry 5: 601 (1966).

19 Nemenson, Y. and $\mathrm{P}$

component of tissue PITLICK, F.A.: Purification and characterization of the protein

20 Nemerson, Y. and SPA tor. Biochemistry 9: 5100 (1970). Blood 23: 657 (1964).

21 OWREN, P.A. and AAs, K.: The control of dicoumarol therapy. J.clin.Lab. Invest. 3:

22 PLAS, P. M. VAN DER: in Human blood coagulation, p. 89 (Leiden University Press,
Leiden 1969).

23 Plas, P. M. VAN DER; KraAn, L., and HeMKer, H.C.: Filipin as a tool for the study of blood coagulation reactions. Thromb. Diath haemorth $27: 584$

C. lation reactions by plood coagu-

25 Sørbye, O.; Phillips, F. C. Abstracts FEBS meeting, p. 273, Madrid 1969. in blood coagulation. Amplification of cholesterol 139 (1971).

26 SWART, A.C.W.: Studies on the purification and separation of blood coagulation factors II, VII, IX and X; thesis, Leiden (1971). 27 WILlIAMS, W.J.: The activity of lung microsomes in blood coagulation. J.biol. Chem.
239: 933 (1964).

28 ZUTPhen, H. van; DeEnen, L.L.M. van, and Kinsky, S.C.: The action of polyene

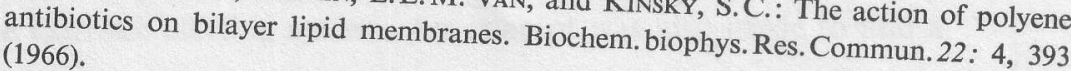

Request reprints from: Dr.P.M.van DER PLAS, Division of Hemostasis and Thrombosis, University Hospital Dijkzigt, Rotterdam (The Netherlands) 